\title{
News the public should rely on
}

\author{
Vincent T DeVita Jr
}

One of the problems that has always adversely influenced peoples' views of the 'war on cancer' has been the confusing public debates by scientists on the causes of cancer. Good news is often drowned out by these debates. We received such good news when the annual report to the nation on the status of cancer between the period 1975-2008 was published online in November 2008 in the Journal of the National Cancer Institute. ${ }^{1}$ The incidence and death rates for all cancers combined are decreasing for both men and women, largely as a result of declines in the most common cancers such as breast, colorectal, prostate and lung cancers.

In 1986, the National Cancer Institute (NCl) published its goals that were set to reduce the incidence and mortality from cancer by the year $2000 .^{2}$ Critics, who always seem to confuse goals (which require proactive programs) with estimates and the straight lining of data, said the goals were unrealistic, and pointed out that incidence and mortality rates were projected to increase by the year 2000 . But, with much effort, by the year 2000, a $15 \%$ decline in mortality was achieved. The American Cancer Society has now set goals and developed programs to decrease mortality by $50 \%$ by the year 2015 . Their midpoint assessment indicates that they are also tracking closer to this target than most critics anticipated. ${ }^{3}$ So, the purveyors of doom and gloom who love to frighten and confuse the public with stories of cancer epidemics caused by a plethora of toxic exposures, have been proven decisively wrong. Most of them have fallen strangely silent, but not all. I had lunch recently with Ron Herberman, Director of the University of Pittsburgh Cancer Center, who made the news by issuing a warning of the carcinogenic risk of cell phones. Dr Herberman
So, the

purveyors

of doom

and gloom

who love to

frighten and

confuse the

public....have

been proven

decisively

wrong.

VT DeVita Jr is the Editor-in-Chief of Nature Clinical Practice Oncology.

\section{Competing interests}

The author declared no competing interests.

www.nature.com/clinicalpractice doi:10.1038/ncponc1301 is an intelligent and honest investigator who would not purposefully mislead, so I asked him the source of his concern. He identified Devra Davis, Head of the Center for Environmental Oncology at his Center and author of the book "The Secret History of the War on Cancer". Her book reminded me of my days at the $\mathrm{NCl}$ when the epidemiologist Samuel Epstein, apparently one of her intellectual mentors, was the purveyor of fear of the chemically induced cancer epidemic that never occurred. As the title suggests, she identifies a conspiracy to cover up environmental carcinogens under every rock, and under one rock she found the cell phone companies. She even implies in the book that during my time as $\mathrm{NCl}$ Director "very highly placed officials at NCl", who were not named of course, were in the pocket of the tobacco industry-which was news to me. So we should consider the source. The data on cell phone use as a cause of cancer is at the moment a curiosity, and I mention it because one certainly does not see reliable evidence of its affect in any of the incidence and mortality data.

Despite considerably more hard data suggesting an association, the statistics do not support another newsworthy carcinogenic influence that was supposed to reverse the decline in incidence and mortality from cancer; the obesity epidemic. I asked an epidemiologist in the field why this reversal had not occurred, and he thought maybe we would see more substantial declines if it were not for the obesity epidemic. But whatever we are doing right, it is powerful enough to overcome risk factors, real or imagined, and that is news the public should rely on.

Supplementary information in the form of a reference list is available on the Nature Clinical Practice Oncology website. 